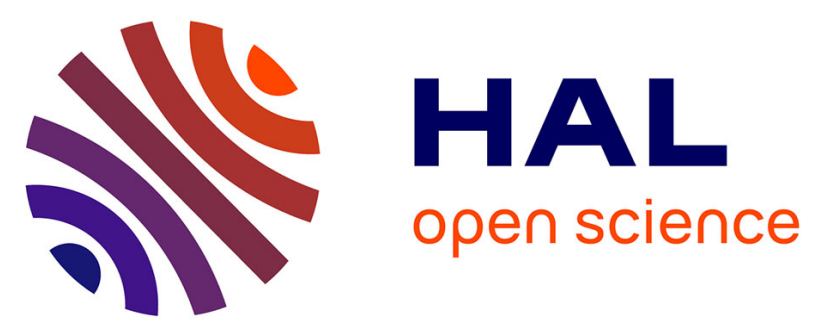

\title{
Socio-economic status and diabetes-related hospital admissions: a cross-sectional study of people with diagnosed diabetes
}

Sarah H Wild, John A Mcknight, Alex Mcconnachie, Robert S Lindsay

\section{- To cite this version:}

Sarah H Wild, John A Mcknight, Alex Mcconnachie, Robert S Lindsay. Socio-economic status and diabetes-related hospital admissions: a cross-sectional study of people with diagnosed diabetes. Journal of Epidemiology and Community Health, 2010, 64 (11), pp.1022. 10.1136/jech.2009.094664 . hal-00560775

\section{HAL Id: hal-00560775 \\ https://hal.science/hal-00560775}

Submitted on 30 Jan 2011

HAL is a multi-disciplinary open access archive for the deposit and dissemination of scientific research documents, whether they are published or not. The documents may come from teaching and research institutions in France or abroad, or from public or private research centers.
L'archive ouverte pluridisciplinaire HAL, est destinée au dépôt et à la diffusion de documents scientifiques de niveau recherche, publiés ou non, émanant des établissements d'enseignement et de recherche français ou étrangers, des laboratoires publics ou privés. 


\section{Socio-economic status and diabetes-related hospital admissions: a cross-sectional study of people with diagnosed diabetes}

Sarah H. Wild ${ }^{1}$, John A. McKnight ${ }^{2}$, Alex McConnachie. ${ }^{3}$, Robert S.Lindsay ${ }^{4}$ on behalf of the Glasgow and Lothian diabetes register data group

${ }^{1}$ Public Health Sciences, University of Edinburgh, Scotland

${ }^{2}$ Metabolic Unit, Western General Hospital, Edinburgh, Scotland

${ }^{3}$ Robertson Centre for Biostatistics, University of Glasgow, Scotland

${ }^{4}$ BHF Cardiovascular Research Centre, University of Glasgow, Scotland

Corresponding author :

Dr Sarah Wild,

Public Health Sciences,

University of Edinburgh,

Teviot Place, Edinburgh,

EH8 9AG, Scotland.

Tel +44 1316511630

Fax +441316506909.

E.mail address: $\underline{\text { Sarah.wild@ed.ac.uk }}$

Key words:

Diabetes complications, socioeconomic status, population register

Word count

Abstract: 199

Main paper (excluding table) : 978

Tables: 1

The Corresponding Author has the right to grant on behalf of all authors and does grant on behalf of all authors, an exclusive licence (or non-exclusive for government employees) on a worldwide basis to the BMJ Publishing Group Ltd and its Licensees to permit this article (if accepted) to be published in Journal of Epidemiology and Community Health and any other BMJPGL products to exploit all subsidiary rights, as set out in its licence (http://jech.bmj.com/ifora/licence.pdf).

JECH/2009/094664. 


\section{What this paper adds}

What is already known on this subject?

Less affluent people with diabetes have poorer outcomes than more affluent people

Inequalities in disease management may contribute to socio-economic differences

in diabetes outcomes

What does this study add?

Differences in prevalence of complications of diabetes by socio-economic status were more marked than differences in disease management measures in this crosssectional study

The role of socio-economic status should be considered when developing risk scores and comparing quality of care between populations of people with diabetes 


\begin{abstract}
Background: Low socio-economic status (SES) is associated with adverse cardiovascular risk factor patterns and poorer outcomes for people with diabetes

Methods: We performed a cross-sectional study using data for 35,925 people with diagnosed diabetes in Scotland and an area-based measure of SES using linked hospital and population-based diabetes register records. Comparisons by quintile of SES were made before (with $\mathrm{p}$ values presented for trend across quintiles given below) and after adjusting for other factors using multivariable logistic regression.

Results: People in the most deprived quintile were more likely than people in the most affluent quintile to have hospital records for diabetic kidney disease (2.4\% vs $2.0 \%$, $\mathrm{p}=0.049)$, diabetic ketoacidosis $(3.5 \%$ vs $3.0 \%, \mathrm{p}=0.11)$, hypoglycaemia $(1.8 \%$ vs $1.4 \%$, $\mathrm{p}=0.008)$, ischaemic heart disease $(22 \%$ vs $17 \%, \mathrm{p}<0.0001)$, stroke $(6.8 \%$ vs $5.1 \%$, $\mathrm{p}<0.0001)$ and peripheral arterial disease $(4.1 \%$ vs $2.1 \%, \mathrm{p}<0.0001)$. An independent effect of SES persisted for cardiovascular disease outcomes after adjusting for age and sex. There were minimal differences in disease management measures by SES. Conclusion: Managing current risk factors equitably is unlikely to remove socioeconomic inequalities in diabetes-related outcomes. Measures of SES may be valuable in risk scores and in making valid comparisons of quality of diabetes care.
\end{abstract}




\section{Introduction}

Inequalities in prevalence of diabetes and its complications by socio-economic status (SES) have been described in many settings. [1] Potential explanations include differences in prevalence of risk factors and access to and use of services. [1-3] Socioeconomic differences in longer term outcomes appear to be more marked than in processes of care as reflected by disease management measures in several health care systems. [4-8]

In Scotland population-based data on people with diagnosed diabetes are collated electronically by capturing data from primary and secondary care systems. [9] We have previously reported that prevalence of type 2 diabetes and of cardiovascular disease among people with diabetes was inversely associated with SES in central Scotland. [10] The aim of this analysis was to investigate the association between SES, current risk factor patterns and history of hospital admission for selected complications of diabetes.

\section{Methods}

We used data available in 2005 for people with diabetes from a population of over 1.5 million people from two Health Boards in central Scotland. Data on most recent risk factor values were extracted from diabetes registers for people with diabetes and linked to hospital admissions data. The study was approved by local research ethics committees, data guardians and the Privacy Advisory Committee of NHS Services Scotland.

Records in which data on age or sex were missing $(8.0 \%)$ or with obvious errors in the date of diagnosis $(0.1 \%)$ were excluded from the analysis. Quintile of SES was assigned 
using the Scottish Index of Multiple Deprivation (SIMD), an area based measure derived from health and administrative data.[11] The health domain includes standardised mortality ratios, hospital episodes related to emergencies, drug and alcohol use, a comparative illness factor, the estimated proportion of the population being prescribed drugs for anxiety, depression or psychosis and the proportion of live singleton births of low birth weight. [11]

Complications of diabetes were identified from hospital record data using International Classification of Disease (ICD) codes (see footnotes to table). Comparisons were made between quintiles of SES using chi-squared tests for trend for the proportions of people with a history of hospital admission for renal disease, diabetes-related emergencies and cardiovascular disease occurring since 1981 when electronic hospital records began. Logistic regression was used to adjust associations between SES and complications of diabetes for confounding factors. All analyses were performed using S-Plus for Windows v6.1 (or later) software.

\section{Results}

There were 35,925 people with diabetes for whom complete data were available on all cardiovascular risk factors (69\% of people on the registers) and $85 \%$ of people had a history of one or more hospital admissions. Mean age fell from 63.5 to 62.2 years of age and the proportion of women increased from $41 \%$ to $49 \%$ from the least to the most deprived quintile $(\mathrm{p}<0.001$ for trend for both age and sex). There were small differences

in disease management measures by SES, for example mean HbA1c, cholesterol level and systolic blood pressure for the least and most deprived quintiles were 7.6 and 7.8\%, 4.4 and $4.3 \mathrm{mmol} / \mathrm{l}$ and 137 and $134 \mathrm{mmHg}$ respectively. There were more marked 
differences between the least and most deprived quintiles in prevalence of smoking (13.4 and $32.4 \%)$ and mean body mass index (29.4 and $31.2 \mathrm{~kg} / \mathrm{m} 2)$.

Proportions of people in each SES quintile with history of a hospital admission for outcomes of interest and results of logistic regression models adjusting for age and sex are shown in the table. Further adjustment for Health Board, smoking status, body mass index, HbA1c, estimated glomerular filtration rate, cholesterol, type and duration of diabetes had modest effects for most outcomes but increased the OR(95\% CI) for diabetic ketoacidosis and hypoglycaemia to $1.67(1.36-2.06)$ and $2.11(1.60-2.78)$ respectively.

\section{Discussion}

We have shown that a history of hospital admission for various complications of diabetes is more common among deprived than affluent people with diabetes. Our finding that there were more marked socio-economic differences in complications of diabetes than among disease management measures are consistent with those of previous studies. [5,1214] A recent cross-sectional study in a Glasgow population concluded that the association of deprivation with atherosclerosis is not adequately explained by classic or emerging risk factors.[15]

This study has a number of limitations including its cross-sectional study design which means that the role of lifetime exposure to risk factors in explaining the association between SES and disease outcomes can not be addressed. Current risk factor levels reflect treated values for many people and presence of complications may lead to more aggressive treatment. Treatment and individual level data on SES were not available. It 
was not possible to remove the health domain from SIMD for this analysis but a previous study suggests that this has little effect on socio-economic health inequalities. [16] Our findings may be influenced by survival bias which would be expected to minimise the effect of SES.

The findings of this and other similar studies suggest that tackling any inequalities in current measures of disease management will, at best, only partly address inequalities in risk of complications of diabetes by SES. A history of complications of diabetes is itself associated with increased risk of future complications and prevention of diabetes and its complications including early treatment of risk factors are therefore crucial for reducing inequalities. The use of risk scores that include a measure of SES may provide a more accurate assessment of risk than those that only use cardiovascular risk factors. [17,18] Prospective studies are needed to investigate whether SES could provide a valuable addition to risk scores for complications of diabetes. In addition, the potential role of SES should be considered when making comparisons of diabetes related outcomes and quality of care between different populations.

Tackling inequalities in health is complex and will only be successful if the social determinants of health are addressed. $[19,20]$ Failure to reduce inequalities in prevalence and complications of diabetes will, however, be detrimental to both individuals and societies. [21,22] 
Table: History of diabetes-related and cardiovascular hospital admissions by socio economic status: numbers, proportion and age-sex adjusted odds ratio (using least deprived quintile- Q1 as reference group)

\begin{tabular}{|c|c|c|c|c|c|c|c|}
\hline \multirow{2}{*}{$\begin{array}{l}\text { Type of } \\
\text { hospital } \\
\text { admission }\end{array}$} & \multicolumn{6}{|c|}{ Quintile of socio-economic status } & \multirow{2}{*}{$\begin{array}{c}\text { Test for } \\
\text { trend } \\
\text { (unadjusted }\end{array}$} \\
\hline & & $\begin{array}{c}1 \\
\text { (least } \\
\text { deprived) }\end{array}$ & 2 & 3 & 4 & $\begin{array}{c}5 \\
\text { (most } \\
\text { deprived) }\end{array}$ & \\
\hline & $\mathrm{N}$ & 6936 & 4551 & 5017 & 7568 & 11853 & \\
\hline \multirow[t]{2}{*}{$\begin{array}{l}\text { Diabetic } \\
\text { kidney disease }\end{array}$} & $\begin{array}{c}\mathrm{N} \\
(\%)\end{array}$ & $\begin{array}{c}142 \\
(2.0 \%)\end{array}$ & $\begin{array}{c}94 \\
(2.1 \%)\end{array}$ & $\begin{array}{c}107 \\
(2.1 \%)\end{array}$ & $\begin{array}{c}178 \\
(2.4 \%)\end{array}$ & $\begin{array}{c}286 \\
(2.4 \%)\end{array}$ & $\mathrm{p}=0.049$ \\
\hline & $\begin{array}{c}\text { OR } \\
(95 \% \mathrm{CI})\end{array}$ & 1.00 & $\begin{array}{c}1.06 \\
(0.81,1.38)\end{array}$ & $\begin{array}{c}1.10 \\
(0.85,1.42)\end{array}$ & $\begin{array}{c}1.22 \\
(0.97,1.52))\end{array}$ & $\begin{array}{c}1.29 \\
(1.05,1.59)\end{array}$ & \\
\hline \multirow[t]{2}{*}{$\begin{array}{l}\text { Diabetic } \\
\text { ketoacidosis }\end{array}$} & $\begin{array}{c}\mathrm{N} \\
(\%)\end{array}$ & $\begin{array}{c}206 \\
(3.0 \%)\end{array}$ & $\begin{array}{c}143 \\
(3.1 \%)\end{array}$ & $\begin{array}{c}188 \\
(3.7 \%)\end{array}$ & $\begin{array}{c}239 \\
(3.2 \%)\end{array}$ & $\begin{array}{c}411 \\
(3.5 \%)\end{array}$ & $\mathrm{p}=0.11$ \\
\hline & $\begin{array}{c}\text { OR } \\
(95 \% \mathrm{CI})\end{array}$ & 1.00 & $\begin{array}{c}0.92 \\
(0.74,1.16)\end{array}$ & $\begin{array}{c}1.20 \\
(0.97,1.48)\end{array}$ & $\begin{array}{c}1.07 \\
(0.87,1.30)\end{array}$ & $\begin{array}{c}1.15 \\
(0.97,1.38)\end{array}$ & \\
\hline \multirow[t]{2}{*}{ Hypoglycaemia } & $\begin{array}{c}\mathrm{N} \\
(\%)\end{array}$ & $\begin{array}{c}95 \\
(1.4 \%)\end{array}$ & $\begin{array}{c}55 \\
(1.2 \%)\end{array}$ & $\begin{array}{c}84 \\
(1.7 \%)\end{array}$ & $\begin{array}{c}116 \\
(1.5 \%)\end{array}$ & $\begin{array}{c}212 \\
(1.8 \%)\end{array}$ & $\mathrm{p}=0.008$ \\
\hline & $\begin{array}{c}\text { OR } \\
(95 \% \mathrm{CI})\end{array}$ & 1.00 & $\begin{array}{c}0.84 \\
(0.60,1.17)\end{array}$ & $\begin{array}{c}1.18 \\
(0.88,1.59)\end{array}$ & $\begin{array}{c}1.10 \\
(0.84,1.45)\end{array}$ & $\begin{array}{c}1.26 \\
(0.99,1.61)\end{array}$ & \\
\hline \multirow[t]{2}{*}{$\begin{array}{l}\text { Ischaemic heart } \\
\text { disease }\end{array}$} & $\begin{array}{c}\mathrm{N} \\
(\%)\end{array}$ & $\begin{array}{c}1180 \\
(17.0 \%) \\
\end{array}$ & $\begin{array}{c}771 \\
(16.9 \%) \\
\end{array}$ & $\begin{array}{c}935 \\
(18.6 \%) \\
\end{array}$ & $\begin{array}{c}1502 \\
(19.8 \%)\end{array}$ & $\begin{array}{c}2588 \\
(21.8 \%)\end{array}$ & $\mathrm{p}<0.0001$ \\
\hline & $\begin{array}{c}\text { OR } \\
(95 \% \mathrm{CI})\end{array}$ & 1.00 & $\begin{array}{c}1.08 \\
(0.98,1.20)\end{array}$ & $\begin{array}{c}1.22 \\
(1.11,1.35)\end{array}$ & $\begin{array}{c}1.31 \\
(1.20,1.42)\end{array}$ & $\begin{array}{c}1.57 \\
(1.45,1.70)\end{array}$ & \\
\hline \multirow[t]{2}{*}{ Stroke } & $\begin{array}{l}\mathrm{N} \\
(\%)\end{array}$ & $\begin{array}{c}355 \\
(5.1 \%) \\
\end{array}$ & $\begin{array}{c}240 \\
(5.3 \%) \\
\end{array}$ & $\begin{array}{c}274 \\
(5.5 \%) \\
\end{array}$ & $\begin{array}{c}490 \\
(6.5 \%) \\
\end{array}$ & $\begin{array}{c}804 \\
(6.8 \%) \\
\end{array}$ & $\mathrm{p}<0.0001$ \\
\hline & $\begin{array}{c}\text { OR } \\
(95 \% \mathrm{CI})\end{array}$ & 1.00 & $\begin{array}{c}1.12 \\
(0.94,1.32)\end{array}$ & $\begin{array}{c}1.15 \\
(0.98,1.36)\end{array}$ & $\begin{array}{c}1.36 \\
(1.18,1.57)\end{array}$ & $\begin{array}{c}1.52 \\
(1.33,1.73)\end{array}$ & \\
\hline \multirow[t]{2}{*}{$\begin{array}{l}\text { Peripheral } \\
\text { arterial disease }\end{array}$} & $\begin{array}{c}\mathrm{N} \\
(\%)\end{array}$ & $\begin{array}{c}146 \\
(2.1 \%)\end{array}$ & $\begin{array}{c}132 \\
(2.9 \%)\end{array}$ & $\begin{array}{c}170 \\
(3.4 \%)\end{array}$ & $\begin{array}{c}255 \\
(3.4 \%)\end{array}$ & $\begin{array}{c}486 \\
(4.1 \%)\end{array}$ & $\mathrm{p}<0.0001$ \\
\hline & $\begin{array}{c}\text { OR } \\
(95 \% \mathrm{CI})\end{array}$ & 1.00 & $\begin{array}{c}1.50 \\
(1.18,1.91)\end{array}$ & $\begin{array}{c}1.76 \\
(1.41,2.21)\end{array}$ & $\begin{array}{c}1.74 \\
(1.41,2.14)\end{array}$ & $\begin{array}{c}2.25 \\
(1.86,2.72)\end{array}$ & \\
\hline
\end{tabular}

ICD codes were used to identify disease groups as follows: diabetic kidney disease (ICD9: 585, 586, 587, 581.8, 583.8, ICD-10: N04, N06, N08, N15, N16, N18), diabetic ketoacidosis (ICD-9: 250.1; ICD-10: E10.1, E11.1, E14.1), hypoglycaemia (ICD-9: 250.8; ICD-10: E16.0, E16.2), ischaemic heart disease (ICD-9: 410-414; ICD-10: I24-25) stroke (ICD-9: 430-438; ICD-10: I60-69), peripheral arterial disease (ICD-9: 443; ICD10: I73). 
Funding

This work was supported by grants from Diabetes UK and the NHS Lothian Research and Development Fund.

Competing interests

None

$\underline{\text { Acknowledgements }}$

We acknowledge with gratitude the work and support of a large number of our colleagues responsible for contributing data, setting up and maintaining the SCI-DC database, particularly Scott Cunningham for his help with data extraction.

\section{References}

1. Brown AF, Ettner SL, Piette J, Weinberger M, Gregg E, Shapiro MF, Karter AJ, Safford M, Waitzfelder B, Prata PA, Beckles GL. Socioeconomic position and health among persons with diabetes mellitus: a conceptual framework and review of the literature. Epidemiol Rev 2004;63-77.

2. Caddick SL, McKinnon M, Payne N, Ward TJ, Thornton-Jones H, Kells J, Ward JD. Hospital admissions and social deprivation of patients with diabetes mellitus. Diabet Med 1994;10:981-983.

3. Unwin N, Binns D, Elliott K, Kelly WF. The relationships between cardiovascular risk factors and socio-economic status in people with diabetes. Diabet Med 1996;1:72-79. 
4. Millett C, Saxena S, Ng A, Mainous A, III, Majeed A. Socio-economic status, ethnicity and diabetes management: an analysis of time trends using the health survey for England. J Public Health (Oxf) 2007;4:413-419.

5. Brown AF, Gregg EW, Stevens MR, Karter AJ, Weinberger M, Safford MM, Gary TL, Caputo DA, Waitzfelder B, Kim C, Beckles GL. Race, ethnicity, socioeconomic position, and quality of care for adults with diabetes enrolled in managed care: the Translating Research Into Action for Diabetes (TRIAD) study. Diabetes Care 2005;12:2864-2870.

6. Maney M, Tseng CL, Safford MM, Miller DR, Pogach LM. Impact of self-reported patient characteristics upon assessment of glycemic control in the Veterans Health Administration. Diabetes Care 2007;2:245-251.

7. Rabi DM, Edwards AL, Southern DA, Svenson LW, Sargious PM, Norton P, Larsen ET, Ghali WA. Association of socio-economic status with diabetes prevalence and utilization of diabetes care services. BMC Health Serv Res $2006 ; 124-$

8. Rabi DM, Edwards AL, Svenson LW, Sargious PM, Norton P, Larsen ET, Ghali WA. Clinical and medication profiles stratified by household income in patients referred for diabetes care. Cardiovasc Diabetol 2007;11-

9. McKnight JA, Morris AD, Cline D, Peden N, Fischbacher C, Wild S. Implementing a national quality assurance system for diabetes care: the Scottish Diabetes Survey 2001-2006. Diabet Med 2008;6:743-746. 
10. Wild S, Macleod F, McKnight J, Watt G, Mackenzie C, Ford I, McConnachie A, Lindsay RS. Impact of deprivation on cardiovascular risk factors in people with diabetes: an observational study. Diabet Med 2008;2:194-199.

11. Office of the Chief Statistician. Scottish Index of Multiple Deprivation 2004: Summary Technical Report.2004;

12. Edwards R, Burns JA, McElduff P, Young RJ, New JP. Variations in process and outcomes of diabetes care by socio-economic status in Salford, UK. Diabetologia 2003;6:750-759.

13. Bihan H, Laurent S, Sass C, Nguyen G, Huot C, Moulin JJ, Guegen R, Le Toumelin P, Le Clesiau H, La Rosa E, Reach G, Cohen R. Association among individual deprivation, glycemic control, and diabetes complications: the EPICES score. Diabetes Care 2005;11:2680-2685.

14. McEwen LN, Kim C, Karter AJ, Haan MN, Ghosh D, Lantz PM, Mangione CM, Thompson TJ, Herman WH. Risk factors for mortality among patients with diabetes: the Translating Research Into Action for Diabetes (TRIAD) Study. Diabetes Care 2007;7:1736-1741.

15. Deans KA, Bezlyak V, Ford I, Batty GD, Burns H, Cavanagh J, de Groot E, McGinty A, Millar K, Shiels PG, Tannahill C, Velupillai YN, Sattar N, Packard CJ. Differences in atherosclerosis according to area level socioeconomic deprivation: cross sectional, population based study. BMJ 2009;b4170- 
16. Adams J, White M. Removing the health domain from the Index of Multiple Deprivation 2004-effect on measured inequalities in census measure of health. $J$ Public Health (Oxf) 2006;4:379-383.

17. Woodward M, Brindle P, Tunstall-Pedoe H. Adding social deprivation and family history to cardiovascular risk assessment: the ASSIGN score from the Scottish Heart Health Extended Cohort (SHHEC). Heart 2007;2:172-176.

18. Hippisley-Cox J, Coupland C, Vinogradova Y, Robson J, May M, Brindle P. Derivation and validation of QRISK, a new cardiovascular disease risk score for the United Kingdom: prospective open cohort study. BMJ 2007;7611:136-

19. Marmot M. Social determinants of health inequalities. Lancet 2005;9464:1099-1104.

20. Link BG, Phelan J. Social conditions as fundamental causes of disease. J Health Soc Behav 1995;80-94.

21. Robbins JM, Vaccarino V, Zhang H, Kasl SV. Excess type 2 diabetes in AfricanAmerican women and men aged 40-74 and socioeconomic status: evidence from the Third National Health and Nutrition Examination Survey. J Epidemiol Community Health 2000;11:839-845.

22. Williams R, Van Gaal L, Lucioni C. Assessing the impact of complications on the costs of Type II diabetes. Diabetologia 2002;7:S13-S17. 